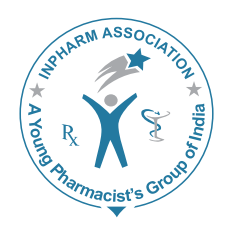

\title{
Aqueous Methanol Extracts of Cochlospermum tinctorium (A. Rich) Possess Analgesic and Anti-inflammatory Activities
}

\author{
Ahmed TS, Magaji MG' ${ }^{1}$, Yaro $\mathrm{AH}^{2}$, Musa $\mathrm{AM}^{3}$, $\mathrm{Adamu} \mathrm{AK}^{4}$ \\ Department of Pharmaceutical Sciences, Federal Government Girls College, New Bussa, Niger State, \\ ${ }^{1}$ Department of Pharmacology and Therapeutics, Ahmadu Bello University, Zaria, ${ }^{2}$ Department of \\ Pharmacology, Bayero University, Kano, ${ }^{3}$ Department of Pharmaceutical and Medicinal Chemistry, and \\ ${ }^{4}$ Department of Biological Sciences, Ahmadu Bello University, Zaria, Nigeria
}

Address for correspondence: Mr. Mohammed G. Magaji; E-mail: magmas1@yahoo.com

\begin{abstract}
Cochlopermum tinctorium A. Rich. (Cochlospermaceae) is a commonly used medicinal plant in the West Africa sub-region for the management of various conditions including pain and inflammatory conditions. In the present study, we report the analgesic and anti-inflammatory activities of the aqueous methanol leaf $(20-80 \mathrm{mg} / \mathrm{kg})$, root $(7.5-30 \mathrm{mg} / \mathrm{kg})$, and root bark $(20-80 \mathrm{mg} / \mathrm{kg})$ extracts of the plant. The analgesic potentials of the extracts were studied using acetic acid induced writhing and hot plate tests in mice while the anti-inflammatory activity was investigated using carrageenan-induced paw edema in rats. The extracts significantly and dose dependently inhibited the acetic acid-induced writhing in mice. However, the highest protection against writhing was produced by aqueous methanol leaf extract at the dose of $80 \mathrm{mg} / \mathrm{kg}$ $(96.65 \%)$ which even was greater than that of the standard agent, ketoprofen $(82.30 \%)$. The extracts did not significantly increase mean latency of response in the hot plate test. However, aqueous methanol root bark extract at the dose of $20 \mathrm{mg} / \mathrm{kg}$ significantly $(P<0.05)$ increased the mean latency of pain response. While the extracts of the root and root bark extracts of the plant afforded non dose-dependent protection against carrageenan-induced edema, the aqueous methanol leaf extract significantly and dose-dependently inhibited carrageenan-induced hind paw edema at the end of the third hour. The present study suggests that the aqueous methanol leaf, root, and root bark extracts of Cochlopermum tinctorium possess analgesic and anti-inflammatory activities which lend some credence to the ethnomedical claim of the use of the plant in the management of pain and inflammatory conditions.
\end{abstract}

Key words: Analgesia, anti-inflammation, Cochlopermum tinctorium, hot plate, edema, writhing

\begin{tabular}{|l|l|}
\hline \multicolumn{2}{|c|}{ Access this article online } \\
\hline Quick Response Code: & \\
\hline & Website: \\
\hline & www.jyoungpharm.in \\
\cline { 2 - 3 } & DOI: \\
\hline
\end{tabular}

\section{INTRODUCTION}

The use of medicinal plants is an ancient practice common to all societies ${ }^{[1]}$ About $80 \%$ of the world population living in developing relies on traditional medicine for their primary health care need. ${ }^{[2]}$ The world Health Organization encourages the inclusion of herbal medicine 
of proven efficacy and safety in health care delivery system of developing countries. ${ }^{[3]}$ There is, therefore, a need to validate the folkloric claim of the medicinal plants used in traditional medicine so that the beneficial ones can be deployed as phytomedicines while the bioactive constituents from such beneficial plants could be isolated and used as "leads" in drug discovery process.

Cochlospermum tintorium (A. Rich) (Cochlospermaceae) is a bushy plant attaining about $50 \mathrm{~cm}$ in height. It has widespread occurrence in the savannah and shrub land throughout the drier areas of West Africa region. The common vernacular names in Nigeria include rawaya, kyamba (Hausa), obazi, abanzi (Igbo), and sewutu (Yoruba). ${ }^{[4]}$

The rhizomes of the plant are used traditionally against fever, hepatitis, abdominal pain, and helminthes, and bilharzias infestations. ${ }^{[5]}$ The decoctions of the whole roots are used as remedy for gonorrhea, jaundice and gastrointestinal disease. ${ }^{[6]}$ Some previous studies on the plant have reported anti-ulcer, radical scavenging, immunomodulating, ${ }^{[7]}$ anti-malarial, ${ }^{[8]}$ hepatoprotective, ${ }^{[9,10]}$ antibacterial, ${ }^{[11,12]}$ anti-convulsant ${ }^{[13]}$ activities. To our knowledge, there is no report on the analgesic and antiinflammatory potentials of the plant in the literature. This study is, therefore, aimed at evaluating the analgesic and anti-inflammatory activities of the aqueous methanol extracts of Cochlospermum tinctorium.

\section{MATERIALS AND METHODS}

The whole plant, Cochlopermum tintorium was collected from a secondary forest in New Bussa, Niger state, Nigeria in January 2008 by Late Mal. Ahmed. Sani Tijjani. The collection was authenticated by Messrs Musa Mohammed and Umar Galla of the Herbarium Section in the Department of Biological Sciences, Ahmadu Bello University (ABU), Zaria-Nigeria by comparing with existing specimen (Number 2314). The parts of the plants namely leaves, root and root bark were cleaned, separated and dried under shade. They were then size-reduced separately into coarse powder with a pestle and mortar. Extraction was carried out using cold maceration with occasional shaking for $72 \mathrm{hr}$ using $500 \mathrm{ml}$ of $70 \%$ aqueous methanol for each $100 \mathrm{~g}$ of powdered material. The extracts were concentrated in vacuo and subsequently referred to as aqueous methanol leaf extract (AMLE), aqueous methanol root extract (AMRE), and aqueous methanol root bark extract (AMRBE), respectively. Fresh aqueous solutions of the extracts were prepared for each study.

\section{Phytochemical studies}

The extracts were screened for the presence of alkaloids, saponins, tannins, flavonoids etc.using standard protocol..$^{[14]}$

\section{Animals}

Albino rats of Wistar strain (150-200 g) and Swiss albino mice (18-30 g) of either sex were procured from the Animal House Facility of the Department of Pharmacology and Therapeutics, Ahmadu Bello University, Zaria, Nigeria. They were housed in standard polypropylene cages and kept under controlled room temperature $\left(25 \pm 2^{\circ} \mathrm{C}\right)$ in a $12 \mathrm{~h}$ light-dark cycle. The animals were fed on standard laboratory animal diet and water ad libitum. Food was withdrawn during the experimental hours. All experimental protocols were approved by the University animal ethics committee and conducted in accordance with standard practice of animal handling as accepted internationally.

Drugs

The following chemicals and drugs were used: carrageenan (Sigma-Aldrich), Acetic acid (Ranbaxy Laboratories Ltd., Punjab), Ketoprofen (Lek, Slovenia), Morphine (Martindale, Essex) and Piroxicam (Roche laboratories, Welwyn Garden City).

Acute toxicity study

Intraperitoneal median lethal dose $\left(\mathrm{LD}_{50}\right)$ estimation was conducted in mice using the method of Lorke. Briefly; the method was divided into two phases. In the initial phase, three groups of three mice each were treated with AMLE at doses of 10,100 , and $1000 \mathrm{mg} / \mathrm{kg}$ body weight i.p. and observed for signs of toxicity and death for $24 \mathrm{~h}$. In the second phase, four groups each containing three mice was injected with four more specific doses of AMLE. The $\mathrm{LD}_{50}$ value was determined by calculating the geometric mean of the lowest dose that caused death and the highest dose for which the animal survived $(0 / 1$ and $1 / 1) \cdot{ }^{[15]}$ The same procedure was conducted for AMRE and AMRBE.

\section{Acetic acid-induced writhing test}

The mice $(n=6)$ were treated with normal saline $(10 \mathrm{ml} /$ $\mathrm{kg})$, AMRE (7.5, 15, and $30 \mathrm{mg} / \mathrm{kg})$, AMLE (20, 40, and $80 \mathrm{mg} / \mathrm{kg}$ ), AMRBE (20, 40, and $80 \mathrm{mg} / \mathrm{kg}$ ), or ketoprofen $(10 \mathrm{mg} / \mathrm{kg})$, intraperitoneally. Thirty minutes after administration, the mice were treated with $0.6(\mathrm{v} / \mathrm{v})$ acetic acid, intraperitoneally and were immediately transferred 
to individual cages. The number of writhes was counted using tally counter for each mouse for a period of $10 \mathrm{~min}$ after 5 min latency period. ${ }^{[16]}$ Percentage inhibitions of writhes were calculated for the extract and the standard agent using the formula:

$$
\text { Inhibition }(\%)=\frac{\begin{array}{l}
\text { Mean Number of writhes }(\text { control }) \\
\text { Mean Number of writhes }(\text { control })
\end{array}}{\text { Mean Number of writhes }(\text { test })}
$$

\section{Hot plate test}

A $600 \mathrm{ml}$ test beaker was placed on thermostat hot plate (Gallenkamp thermostat). The temperature was regulated to $50 \pm 1^{\circ} \mathrm{C}$. Each mouse was placed in the beaker (on the hot plate) in order to obtain its response to electrical heatinduced nociceptive pain stimulus. Licking of the paws or jumping out of the beaker was taken as an indicator of the animal's response to heat-induced nociceptive pain stimulus. The time for each mouse to lick its paws or jump out of the beaker was taken (reaction time). Each mouse serves as its own control. Before treatment, its reaction time was taken thrice at $1 \mathrm{~h}$ interval. The mean of these three determinations constituted initial reaction time before treatment of the mouse. The mean reaction time for the groups was pooled to obtain the final control mean reaction time $(\mathrm{Tb})$. Each of the test mice was thereafter treated with either normal saline $(10 \mathrm{ml} / \mathrm{kg}), \operatorname{AMRE}(7.5,15$, and $30 \mathrm{mg} / \mathrm{kg}$ ), AMLE (20, 40, and $80 \mathrm{mg} / \mathrm{kg}$ ), AMRBE (20, 40 , and $80 \mathrm{mg} / \mathrm{kg}$ ), intraperitoneally or morphine sulphate ( $5 \mathrm{mg} / \mathrm{kg}$ ), subcutaneously. Thirty minute after treatment, the reaction time of each mouse was again evaluated but only once on this occasion. This was pooled for the mice in each treatment group and the final test mean value (Ta) for each treatment group was calculated. ${ }^{[17,18]}$ This final test mean $(\mathrm{Ta})$ value represented the after treatment reaction time (Ta) and was subsequently used to determine the percentage thermal pain stimulus or protection by applying the formula:

$\%$ protection against thermal stimulus

$$
=\frac{\text { Test mean }(\mathrm{Ta})-\text { Control mean }(\mathrm{Tb})}{\text { Control mean }(\mathrm{Tb})} \times 100
$$

\section{Carrageenan-induced hind paw edema}

Wister rats were divided into five groups each containing five rats. The rats were treated with normal saline $(1 \mathrm{ml} / \mathrm{kg})$, AMRE (7.5, 15, and $30 \mathrm{mg} / \mathrm{kg})$, AMLE (20, 40, and $80 \mathrm{mg} / \mathrm{kg}), \operatorname{AMRBE}(20,40$, and $80 \mathrm{mg} / \mathrm{kg}$ ), or ketoprofen (20 mg/kg), intraperitoneally. Thirty minutes later, $0.1 \mathrm{ml}$ of freshly prepared carrageenan suspension $(1 \%, \mathrm{w} / \mathrm{v}$, in $0.9 \%$ normal saline) was injected into the sub plantar region of the left hind paw of each rat. ${ }^{[19]}$ The paw diameter was measured with the aid of a vernier caliper at $0,1,2,3,4 \mathrm{~h}$ after the injection of carrageenan. The difference between the readings at time $0 \mathrm{~h}$ and different time interval was taken as the thickness of edema. The percentage inhibition of inflammation was calculated for each dose at different hours.

Statistical analysis

The results were presented as mean \pm SEM and were analyzed using one-way ANOVA followed by Dunnett's test for multiple comparisons. A $P$ value $<0.05$ was considered significant.

\section{RESULTS}

\section{Acute toxicity study}

The intraperitoneal median lethal doses of AMRE, AMLE, and AMRBE in mice were found to be 118.32, 288.53, and $288.53 \mathrm{mg} / \mathrm{kg}$, respectively.

\section{Preliminary phytochemical studies}

All the extracts were found to contain saponins, flavonoids, tannins, steroids, cardiac glycosides, and alkaloids [Table 1].

Acetic acid-induced writhing test in mice

The extracts significantly and dose dependently inhibited the acetic acid induced writhing in mice, However, the highest protection against writhing was produced by AMLE at the dose of $80 \mathrm{mg} / \mathrm{kg}(96.65 \%)$ which was greater than that of the standard agent, ketoprofen (82.30\%) [Table 2].

\section{Hot plate test in mice}

The extracts at the various doses tested afforded varying protection against thermal stimulus in mice. However, the increases in mean latency in response were not statistically significant. However, AMRBE significantly $(P<0.05)$ increased the mean latency of pain response. The standard agent, morphine afforded more than $400 \%$ protection against thermal stimulus [Table 3].

Table 1: Phytochemical constituents present in the aqueous methanol extracts of $\mathrm{C}$. tinctorium

\begin{tabular}{lccc}
\hline Phytochemical constituents & AMRE & AMRBE & AMLE \\
\hline Flavonoids & + & + & + \\
Tannins & + & + & + \\
Steroids/terpenoids & + & + & + \\
Cardiac glycoside & + & + & + \\
Alkaloids & + & + & + \\
Saponins & + & + & + \\
\hline
\end{tabular}


Carrageenan-induced hind paw edema

AMRE did not significantly reduced the mean paw diameter at the lowest dose tested $(7.5 \mathrm{mg} / \mathrm{kg})$. AMRBE significantly reduced edema in rats at the third hour after treatment with carrageenan. However, the effect was not dose dependent. AMLE significantly and dosedependently protected the rats against carrageenan-induced edema. The highest activity obtained with the dose of $80 \mathrm{mg} / \mathrm{kg}$ was greater than that produced by ketoprofen at the third hour [Table 4].

\section{DISCUSSION}

The data presented in this study showed that aqueous leaf, root and root bark extracts of Cocblospermum tinctorium possess significantly analgesic and anti-inflammatory activities. The median lethal dose of the extracts found to be less than $300 \mathrm{mg} / \mathrm{kg}$ suggested that they are relatively toxic, ${ }^{[20]}$

Table 2: Effect of aqueous methanol extracts of Cochlospermum tinctorium against acetic acid induced writhing in mice

\begin{tabular}{lccc}
\hline Treatment & $\begin{array}{c}\text { Doses } \\
(\mathrm{mg} / \mathrm{kg})\end{array}$ & $\begin{array}{c}\text { Mean number of } \\
\text { writhes } \pm \text { SEM }\end{array}$ & $\begin{array}{c}\text { Percentage } \\
\text { inhibition }\end{array}$ \\
\hline Normal saline & $10 \mathrm{ml} / \mathrm{kg}$ & $29.83 \pm 2.90$ & \\
AMRE & 7.5 & $14.50 \pm 2.67^{\mathrm{a}}$ & 51.39 \\
& 15 & $13.83 \pm 3.92^{\mathrm{b}}$ & 53.63 \\
& 30 & $12.33 \pm 2.94^{\mathrm{c}}$ & 58.67 \\
AMLE & 20 & $4.50 \pm 2.16^{\mathrm{c}}$ & 84.91 \\
& 40 & $2.67 \pm 0.67^{\mathrm{c}}$ & 91.05 \\
AMRBE & 80 & $0.83 \pm 0.54^{\mathrm{c}}$ & 96.65 \\
& 20 & $7.33 \pm 2.50^{\mathrm{c}}$ & 75.43 \\
& 40 & $8.17 \pm 2.51^{\mathrm{c}}$ & 72.61 \\
KETO & 80 & $2.83 \pm 0.95^{\mathrm{c}}$ & 90.51 \\
One-way ANOVA & 10 & $5.28 \pm 2.16^{\mathrm{c}}$ & 82.30 \\
& $\mathrm{DF}: 10,55$ & & \\
& $F=11.596$ & & \\
\hline
\end{tabular}

$n=5 .{ }^{\mathrm{a} P} P<0.05 ;{ }^{\mathrm{b}} P<0.01 ;{ }^{\mathrm{c}} P<0.001$ (Dunnett's post-hoc test for multiple comparison) intraperitoneally. However, they may be relatively safe at the analgesic and anti-inflammatory doses used for this study. The ability of the extracts to attenuate the acetic acid-induced writhing in mice suggests that they possess analgesic activity. The writhing response of the mouse to intraperitoneally injected noxious chemicals such as acetic acid is used to screen for both central and peripheral analgesic activity. ${ }^{[1]}$ The intraperitoneal injection of acetic acid produces an abdominal writhing response due to sensitization of chemosensitive nociceptors by prostaglandins. ${ }^{[2]}$ The acetic acid-induced writhing test is very sensitive and able to detect analgesic effects of compounds at dose levels that may appear inactive in other analgesic screening tests. ${ }^{[23}$ However, the test is not predictive whether the activity is centrally or peripherally mediated. ${ }^{[24]}$

Intraperitoneal injection of acetic acid has been reported to significantly increase level of prostanoids, particularly

\begin{tabular}{|c|c|c|c|}
\hline Treatment & $\begin{array}{c}\text { Doses } \\
(\mathrm{mg} / \mathrm{kg})\end{array}$ & $\begin{array}{c}\text { Mean latency } \\
\text { of response }\end{array}$ & $\begin{array}{c}\% \text { Protection against } \\
\text { thermal stimulus }\end{array}$ \\
\hline Control $(n=55)$ & & $1.56 \pm 0.04$ & - \\
\hline \multirow[t]{3}{*}{ AMRE } & 7.5 & $2.83 \pm 0.34$ & 83.77 \\
\hline & 15 & $2.93 \pm 0.28$ & 87.82 \\
\hline & 30 & $3.13 \pm 0.28$ & 100.64 \\
\hline \multirow[t]{3}{*}{ AMLE } & 20 & $2.72 \pm 0.27$ & 74.36 \\
\hline & 40 & $2.83 \pm 0.35$ & 83.77 \\
\hline & 80 & $2.35 \pm 0.26$ & 50.64 \\
\hline \multirow[t]{3}{*}{ AMRBE } & 20 & $3.58 \pm 0.71^{\mathrm{a}}$ & 129.49 \\
\hline & 40 & $2.35 \pm 0.17$ & 50.64 \\
\hline & 80 & $3.08 \pm 0.33$ & 97.44 \\
\hline Normal saline & $10 \mathrm{ml} / \mathrm{kg}$ & $1.70 \pm 0.12$ & 8.97 \\
\hline Morphine & 5 & $9.27 \pm 0.92^{\mathrm{c}}$ & 494.23 \\
\hline One-way ANOVA & $\begin{array}{l}\text { d.f. } 10,55 \\
F=22.019 \\
\alpha<0.001\end{array}$ & & \\
\hline
\end{tabular}

$n=6 .{ }^{a} P<0.05 ;{ }^{\mathrm{c}} P<0.001$ (Dunnett's post-hoc test for multiple comparison)

Table 4: Effect of aqueous methanol extracts of Cochlospermum tinctorium against edema in rats mice

\begin{tabular}{|c|c|c|c|c|c|}
\hline \multirow[t]{3}{*}{ Treatment } & \multirow[t]{3}{*}{ Dose (mg/kg) } & \multicolumn{4}{|c|}{ Mean paw diameter $(\mathrm{cm} \pm \mathrm{SEM})$} \\
\hline & & \multicolumn{4}{|c|}{ Time (h) } \\
\hline & & 1 & 2 & 3 & 4 \\
\hline$N /$ saline & $1 \mathrm{ml} / \mathrm{kg}$ & $0.162 \pm 0.014$ & $0.166 \pm 0.032$ & $0.238 \pm 0.031$ & $0.158 \pm 0.031$ \\
\hline \multirow[t]{3}{*}{ AMRE } & 7.5 & $0.128 \pm 0.007(20.98)$ & $0.128 \pm 0.010(22.89)$ & $0.176 \pm 0.017^{\mathrm{NS}}(26.05)$ & $0.112 \pm 0.005(29.11)$ \\
\hline & 15 & $0.128 \pm 0.001(20.98)$ & $0.116 \pm 0.004(30.12)$ & $0.150 \pm 0.016^{\mathrm{b}}(36.97)$ & $0.102 \pm 0.002^{\mathrm{a}}(36.57)$ \\
\hline & 30 & $0.148 \pm 0.010(8.64)$ & $0.128 \pm 0.019(22.89)$ & $0.162 \pm 0.014^{\mathrm{a}}(31.93)$ & $0.124 \pm 0.007(21.52)$ \\
\hline \multirow[t]{3}{*}{ AMRBE } & 20 & $0.082 \pm 0.013^{\mathrm{c}}(49.38)$ & $0.098 \pm 0.010^{\mathrm{b}}(40.96)$ & $0.118 \pm 0.012^{\mathrm{c}}(50.42)$ & $0.082 \pm 0.007^{\circ}(48.10)$ \\
\hline & 40 & $0.098 \pm 0.013^{\mathrm{b}}(39.51)$ & $0.100 \pm 0.011^{\mathrm{b}}(39.76)$ & $0.120 \pm 0.010^{\mathrm{c}}(49.58)$ & $0.092 \pm 0.009^{\mathrm{b}}(41.77)$ \\
\hline & 80 & $0.068 \pm 0.012^{\mathrm{c}}(58.02)$ & $0.080 \pm 0.010^{\mathrm{c}}(51.80)$ & $0.078 \pm 0.018^{\mathrm{c}}(67.23)$ & $0.054 \pm 0.004^{c}(41.65)$ \\
\hline \multirow[t]{3}{*}{ AMLE } & 20 & $0.116 \pm 0.013^{\mathrm{a}}(28.40)$ & $0.116 \pm 0.005(30.12)$ & $0.146 \pm 0.011^{\mathrm{b}}(38.66)$ & $0.084 \pm 0.004^{c}(29.64)$ \\
\hline & 40 & $0.076 \pm 0.012^{\mathrm{c}}(53.09)$ & $0.090 \pm 0.004^{\mathrm{b}}(45.78)$ & $0.136 \pm 0.014^{\mathrm{c}}(42.85)$ & $0.076 \pm 0.011^{\mathrm{c}}(51.90)$ \\
\hline & 80 & $0.070 \pm 0.003^{\mathrm{c}}(56.79)$ & $0.076 \pm 0.008^{c}(54.22)$ & $0.080 \pm 0.009^{\mathrm{c}}(66.39)$ & $0.076 \pm 0.009^{\mathrm{c}}(51.90)$ \\
\hline KETO & 20 & $0.064 \pm 0.007^{\mathrm{c}}(60.49)$ & $0.088 \pm 0.012^{\mathrm{b}}(46.99)$ & $0.114 \pm 0.006^{\mathrm{c}}(52.10)$ & $0.072 \pm 0.011^{\mathrm{c}}(54.42)$ \\
\hline
\end{tabular}

${ }^{\mathrm{a} P} P<0.05$; ${ }^{\mathrm{b}} P<0.01 ;{ }^{\mathrm{c}} P<0.001$; ${ }^{\mathrm{NS}}$ not significant (Dunnett's test for multiple comparison); Figures in parentheses represent percentage inhibition of inflammation 
$\mathrm{PGE}_{2}$ and $\mathrm{PGF}_{2 \alpha}{ }_{22}^{[2]}$ as well as lipoxygenase $\operatorname{products}^{[26]}$ in the peritoneal fluid. In the acetic acid induced writhing test, the abdominal constriction is sensitive to drugs with analgesic activity similar to aspirin, antagonists of kinin receptors as well as the centrally and peripherally acting opioid analgesics. ${ }^{[27,28]}$ The analgesic effect of the extracts may, therefore, be due either to their action on visceral receptors sensitive to acetic acid, to the inhibition of the production of algogenic substances or the inhibition at the central level of the transmission of painful messages. Hot plate test is one of the most common tests of nociception that is based on a phasic stimulus of high intensity. ${ }^{[29]}$ Thermally induced pain in hot plate test is specific for centrally mediated nociception. ${ }^{[30]}$ The inability of the extracts to significantly prolong the reaction latency to thermally-induced pain in mice suggests that their analgesic activity may be peripherally mediated.

Carrageenan-induced inflammatory process is believed to be bi-phasic. ${ }^{[31]}$ The initial phase seen at the 1 st hour is attributed to the release of histamine and serotonin. ${ }^{[32]}$ The second phase which occurs during the $2^{\text {nd }}$ to $3^{\text {rd }}$ hours is due to the release of prostaglandins, bradykinins, and lysosome. The ability of the extracts to significantly reduce the paw edema suggests that they possess anti-inflammatory activities.

The coexistence of analgesic and anti-inflammatory activities is well defined for various non-steroidal anti-inflammatory drugs (NSAIDs), particularly salicylates and their congeners. The principal therapeutic effects of NSAIDs are derived from their ability to inhibit prostaglandin $\mathrm{G} / \mathrm{H}$ synthase (cyclooxygenase or COX), which convert arachidonic acid to the unstable intermediates $\mathrm{PGG}_{2}$ and $\mathrm{PGH}_{2}$, and leads to the production of thromboxane $\mathrm{A}_{2}$ and a variety of prostaglandins. ${ }^{[33]}$ Prostaglandins are also known to cause painand NSAIDs are particularly effective when inflammation has caused sensitization of pain receptors to normally painless mechanical or chemical stimuli. ${ }^{[34]} \mathrm{It}$ is of interest therefore, that the extracts behaved similar to the NSAIDs in this study.

Flavonoids, tannins and saponins have been reported to possess analgesic and anti-inflammatory activities. ${ }^{[35-38]}$ It is, therefore, plausible to suggest that these phytochemical constituents which have been found to be present in the various aqueous methanol extracts of Cochlospermum tinctorium may be responsible for the observed effects.

In conclusion, the findings of this study suggests that the aqueous methanol root, leaf and root bark extracts of Cochlospermum tinctorium possess significant analgesic and anti-inflammatory activities in laboratory animals and lend credence to the ethnomedical use of the plant in the management of pain and inflammatory conditions.

Further work is going on in our laboratory to isolate and characterize the bioactive compound(s) responsible for the observed analgesic and anti-inflammatory activities of various extracts evaluated in this study.

\section{DEDICATION}

The authors wish to dedicate this work to the loving memory of Late Tijjani Ahmed Sani whose MSc thesis constitute the cornerstone of this work.

\section{REFERENCES}

1. Usman H, Yaro AH, Garba MM. Analgesic and anti-inflammatory screening of Newbouldia laevis flower in rodents. Trends Med Res2008;3:10-5.

2. Farnsworth N. Screening plant for new medicines. In: Wilson EO, Editor. Biodiversity. Washington DC: Natural Academy press; 1998.

3. Amos S, Kolawole E, Akah P, Wambebe C, Gamaniel K. Behavioral effects of the aqueous extract of Guiera senegalensis in mice and rats. Phytomedicine 2001;8:356-61.

4. Burkill HM. The useful plants of west tropical Africa. Kew: Botanical Gardens;1985.

5. Traoré M, Guiguemdé A, Yago I, Nikièma JB, Tinto H, Dakuyo ZP, et al. Investigation of antiplasmodial compounds from two plants, Cochlospermum tinctorium A, Rich and Gardenia sokotensis. Afr J Tradit Complement Altern Med 2006;3:34-41.

6. Mann A, Gbate M, Umar AN. Medicinal and economic plants of Nupeland. Bida: Jube-Evans Books and Publications; 2003.

7. Nergard CS, Diallo D, Inngjerdingen K, Michaelsen TE, Kiyohara H, Yamada $\mathrm{H}$, et al. Medicinal use of Cochlospermum tinctorium in Mali: Antiulcer-, radical scavenging - and immunomodulating activities of polymers in the aqueous extract of the roots. J Ethnopharmacol 2005;96:255-69.

8. Benoit F, Valentin A, Pelissier Y, Marion C, Dakuyo Z, Mallie M, et al. Antimalarial activity in vitro of Cocblospermum tinctorium tubercle extracts. Trans R Soc Trop Med Hyg 1995;89:217-8.

9. Diallo B, Vanhaelen M, Kiso Y, Hikino H. Antihepatotoxic actions of Cochlospermum tinctorium rhizomes. J Ethnopharmacol 1987;20:239-43.

10. Etuk EU, Agaie BM, Ladan MJ, Garba I. The modulatory effect of Cochlospermum tinctorium a rich aqueous root extract on liver damage induced by carbon tetrachloride in rats. Afr J Pharm Pharmacol 2009;3:151-7.

11. Tijjani MB, Bello IA, Aliyu AB, Olurishe T, Maidawa SM, Habila JD, et al. Phytochemical and antibacterial studies of root extract of Cochlospermum tinctorium A. rich. (Cochlospermaceae). Res J Med Plants2009;3:16-22.

12. Magaji MG, Shehu A, Musa AM, Sani MB, Yaro AH. Pharmacological evidence on the folkloric use of Cochlospermum tintorium A. Rich. in the management of diarrhea. Int J Pure Appl Sci 2010;4:14-20.

13. Maiha BB, Magaji MG, Yaro AH, Hamza AH, Magaji RA. Anticonvulsant Studies on Cochlospermum tinctorium and Paullinia pinnata extracts in laboratory animals.Niger J Pharm Sci 2009;8:102-8.

14. Silva GL, Lee I, Kinghorn AD. Special problems with the extraction of plants.In: Cannell RJ,editor. Methods in Biotechnology (Natural product Isolation). New Jersey: Humana Press;1998.

15. Lorke D. A new approach to acute toxicity testing. Arch Toxicol 1983;54:275-87.

16. Koster R, Anderson M, de Beer EJ. Acetic acid for analgesic screening. Fed Proc 1959;18:412.

17. Lanhers MC, Fleurentin J, Mortier F, Vinche A, Younos C. Antiinflammatory and analgesic effects of an aqueous extract of Harpagophytum procumbens. Planta Med 1992;58:117-23. 
18. Mahomed IM, Ojewole JA. Analgesic, anti-inflammatory and antidiabetic properties of Harpagophytum procumbens DC (Pedaliaceae) secondary root aqueous extract. Phytother Res 2004;18:982-9.

19. Winter CA, Riselay EA, Nuss GW. Carragenan induced oedema in the hind paw of the rats as an assay for anti - inflammatory drugs. Proc Soc Exp Biol Med 1962;111:544-7.

20. Matsumura F. Toxicology of Insecticides. New York: Plenum press;1975.

21. Trongsakul SA, Panthong D, Kanjanapothi T, Taesotikul T. The analgesic, antipyretic and anti-inflammatory activity of Diospyros variegate Kruz. J Ethnopharmacol 2003;85:221-5.

22. Sutharson L, Lila KN, Presanna KK, Shila EB, Rajan VJ. Antiinflammtory and antinociceptive activities of methanolic extract of the leaves of Fraxinus floribunda Wallich. Afr J Biotechnol 2007;6:582-5.

23. Bentley GA, Newtons SH, Starr J. Studies on the antinociceptive action of agonist drugs and their interaction with opioid mechanisms. Br J Pharmacol 1983;79:125-34.

24. Chan YF, Tsai HY, Wu TS. Anti-inflammatory and analgesic activity of extracts from roots of Angelica pubescens. Planta Med 1995;61:2-8.

25. Derardt R, Jongney S, Delvalcee F, Falhout M. Release of prostaglandins E and $F$ in an algogenic reaction and its inhibition. Eur J Pharmacol 1980;51:17-24.

26. Dhara AK, Suba V, Sen T, Pal S, Chaudhuri AK. Preliminary studies on the anti-inflammatory and analgesic activity of methanolic fraction of the root of Tragia involucrate.J Ethnopharmacol 2000;72:265-8.

27. Barber A, Bartoszyk GD, Bender HM, Gottschlich R, Greiner HE, Harting J, et al. A Pharmacological profile of the novel peripherally-selective k-opioid receptor agonist, EMD 61753. Br J Pharmacol 1994;113:1317-27.

28. Brignola G, Calignano A, Di Rosa M. Modulation of morphine antinociception in the mouse by endogenous nitric oxide. Br J Pharmacol 1994;113:1372-6.

29. Mandegary A, Sayyah M, Heidari MR. Antinociceptive and antiinflammatory activity of the seed and root extracts of Ferula gummosa Boiss in mice and rats. DARU J Pharm Sci 2004;12:58-62.

30. Parkhouse J, Pleuvry BJ. Analgesic drugs. Oxford: Blackwell Co.; 1979.
31. Vinegar R, Schreiber W, Hugo R. Biphasic development of carrageenin edema in rats.J Pharmacol Exp Ther 1969;166:96-103.

32. Crunkhon P, Meacock SE. Mediators of inflammation induced in rats paw by carrageenan. Br J Pharmacol 1971;42:392-402.

33. Burke A, Smyth E, FitzGerald GA. Analgelsic-antipyretic agents; Pharmacotherapy of Gout. In: Brunton LL, Lazo JS, Parker KL,editors. Goodman and Gilman: Pharmacological basis of therapeutics. $11^{\text {th }} \mathrm{ed}$. New York: McGraw Hill Co Inc.; 2006.

34. Roberts JL, Morrow JD. Analgesic, Antipyretic and Anti-inflammatory Agents and Drugs employed in the treatment of Gout. In: Hardman JG, Limbird LE, editors. Goodman and Gilman's the pharmacological basis of therapeutics. $10^{\text {th }}$ ed. New York: McGraw Hill Co Inc.; 2002.

35. Ahmadiani A, Hosseiny J, Semnanian S, Javan M, Saeedi F, Kamalinejad M, et al. Antinociceptive and anti-inflammatory effects of Elaeagnus angustifolia fruit extract. J Ethnopharmacol 2000;72:287-92.

36. Reanmongkol W, Subhadhirasakul S, Thienmontree S, Thanyapanit K, Kalnaowakul J, Sengsui S. Antinociceptive activity of the alkaloid extract from Kopsia macrophylla leaves in mice. Songklanakarin J Sci Technol 2005; 27(Supplement -2): 509-12 URL: http://www.rdoapp.psu.ac.th/html/sjst/ journal/27-Suppl-2/07-Kopsia-macrophylla.pdf

37. de Araujo PF, Coelho-de-Souza AN, Morais SM, Ferreira SC, LealCardoso JH. Antinociceptive effects of the essential oil of Alpinia zerumbet on mice. Phytomedicine 2005;12:482-6.

38. Choi J, Jung H, Lee K, Park H. Antinociceptive and Antiinflammatory effects of saponin and sapogenin obtained from the stem of Akebia quinata. J Med Food 2005;8:78-85.

How to cite this article: Ahmed TS, Magaji MG, Yaro AH, Musa AM, Adamu AK. Aqueous methanol extracts of Cochlospermum tinctorium (A. Rich) possess analgesic and anti-inflammatory activities. J Young Pharmacists 2011;3:237-42.

Source of Support: Nil, Conflict of Interest: None declared.

\section{Author Query \\ Q1: Dedication or Acknowledgement???}

\section{New features on the journal's website}

Optimized content for mobile and hand-held devices

HTML pages have been optimized of mobile and other hand-held devices (such as iPad, Kindle, iPod) for faster browsing speed.

Click on [Mobile Full text] from Table of Contents page.

This is simple HTML version for faster download on mobiles (if viewed on desktop, it will be automatically redirected to full HTML version)

\section{E-Pub for hand-held devices}

EPUB is an open e-book standard recommended by The International Digital Publishing Forum which is designed for reflowable content i.e. the text display can be optimized for a particular display device.

Click on [EPub] from Table of Contents page.

There are various e-Pub readers such as for Windows: Digital Editions, OS X: Calibre/Bookworm, iPhone/iPod Touch/iPad: Stanza, and Linux: Calibre/Bookworm.

\section{E-Book for desktop}

One can also see the entire issue as printed here in a 'flip book' version on desktops.

Links are available from Current Issue as well as Archives pages.

Click on 9 View as eBook 